\title{
UV Radiation, not European Ancestry, Explains States' Cognitive Performance in Brazil and USA
}

La radiación UV, no el ancestro europeo, explica el desempeño cognitivo de los estados en Brasil y Estados Unidos

Federico R. León

Universidad San Ignacio de Loyola, Lima, Perú

(iD https://orcid.org/oooo-0oo2-2290-6837

Correspondencia: federicorleone@gmail.com

Mayra Antonelli-Ponti

Universidade de São Paulo, Ribeirão Preto, Brasil

(iD) https://orcid.org/oooo-0oo3-4931-2788

Correo electrónico: Antonelli.may@gmail.com

Andrés Burga-León

Universidad de Lima, Lima, Perú

(iD) https://orcid.org/oooo-0oo3-0388-4238

Correo electrónico: aburga@ulima.edu.pe

\begin{abstract}
A debate in Mankind Quarterly positing racial categorization of populations vis-à-vis biological effects of UV radiation was based on data from a single country, used absolute latitude instead of UV radiation, and limited the analysis to path analysis. To overcome limitations of the studies, we utilized measurements of UV radiation for 26 Brazilian and 48 USA states instead of absolute latitude and performed seemingly unrelated regressions in addition to path analysis. NAEP scores and infectious disease rate were collected in USA and PISA scores and infant mortality in Brazil. Significant cognitive effects of European ancestry were replicated, but showed spuriousness, disappearing when the effects of UV radiation were controlled. Our evidence strongly suggests that $U V$ radiation is a consistent antecedent of cognitive ability directly and through income in the USA and Brazil and through infant mortality in Brazil, whereas European ancestry only influences cognitive ability positively by reducing infectious diseases in the USA or infant mortality in Brazil. The between-country consistency
\end{abstract}


of our findings compensates for methodological weaknesses that took place especially in the Brazil study. Psychologists and economists should be aware of these findings to avoid making erroneous inferences based on genetic or cultural variables.

Keywords: Cognitive ability, European ancestry, UVradiation, income, Brazil, USA.

\section{Resumen}

Un debate nature-nurture al explicar diferencias en desempeño cognitivo se refirió a la latitud absoluta en USA y usó path analysis como única técnica estadística. Aquí utilizamos datos brasileños ( $N=26$ estados) y norteamericanos ( $N=48$ estados), la radiación UV fue medida directamente y agregamos regresiones aparentemente no relacionadas. Usamos puntajes PISA y mortalidad infantil en Brasil y puntajes NAEP y tasas de infección en Estados Unidos. En los dos países, el ancestro europeo emergió significativamente relacionado con el ingreso per cápita y la radiación UV con el desempeño cognitivo. La radiación UV fue un antecedente consistente del desempeño cognitivo directamente y a través del ingreso en Estados Unidos y Brasil y a través de la mortalidad infantil en Brasil, mientras que el ancestro europeo mejoró el desempeño cognitivo solamente al reducir la mortalidad infantil en Brasil. Las correlaciones entre ancestro europeo y mediciones cognitivas reportadas en la literatura son espurias. La consistencia entre-países de los hallazgos clave obtenidos aquí compensa las debilidades metodológicas que no fue posible superar. Psicólogos y economistas deben prestar atención a estos hallazgos para evitar hacer inferencias erróneas basadas en conceptos genéticos o culturales cuando se omite variables climáticas. Palabras clave: Habilidad cognitiva, ancestro europeo, radiación UV, ingreso, Brasil, USA.

\section{Introduction}

Psychologists frequently compare the effects of heredity and environment on human and animal behavior, although almost always using individuals (e.g., Rushton \& Jensen, 2010; Sauce \& Matzel, 2018) and very unfrequently using population groups as the units of analysis (e.g., Becker \& Rindermann, 2016; León \& Burga-León, 2015). The research presented in this article is a 2-part follow-up of a debate between León (2016) and Fuerst and Kirkegaard (2016a, 2016b) entailing ancestry versus geography as antecedents of intelligence at state level in the USA. Fuerst and Kirkegaard (2016a) conducted a study on the relationships between European ancestry, cognitive ability, and socioeconomic outcomes among countries of the Americas and within Brazil, Colombia, Mexico, and the United States. They reported that European ancestry explained the between and within country differences observed in the latter variables and attributed such differences to genomic determinants. But León and Burga-León (2014, 2015) had reported that cognitive 
ability increases with distance from the equator and attributed the IQ-latitude relationship to UV radiation's (UVR) impairment of biological functions. Viewing Fuerst and Kirkegaard's (2016a) findings in a geographic perspective, León (2016) evaluated their genetic postulate analyzing NAEP (National Assessment of Educational Progress) math and verbal scores of American children across USA states. Rindermann (2007) had already demonstrated that intelligence tests and standardized educational assessments measure the same construct when large population groups are the units of analysis. León (2016) concluded that the European ancestry-cognitive ability relationship in the USA was spurious and criticized Fuerst and Kirkegaard's (2016a) conclusion that inherited intelligence explains differences in cognitive ability between USA states. In their rejoinder, Fuerst and Kirkegaard (2016b) questioned predictions from UVR theory on theoretical grounds and showed between-country data from the Americas indicating direct effects of European ancestry on cognitive ability controlling for absolute latitude. Subsequently, Kirkegaard and Fuerst (2017) utilized Argentinian data to show that skin brightness predicts cognitive ability controlling for latitude.

A problem with the León (2016), Fuerst and Kirkegaard (2016b), and Kirkegaard and Feurst (2017) studies is that they addressed absolute latitude, not UVR. Albeit the relationship between the two variables is strong, it is far from perfect; for example, a zone of higher altitude above sea level may be associated with greater UVR than a zone at sea level closer to the equator because UVR increases with altitude (Dvorkin \& Streinberger, 1999; Engelsen et al., 2005; León \& Avilés, 2016). Other interferences are likely. For example, UVR is paradoxically greater in northern than southern China, probably owing to differences in aerosol optical depth, ozone column concentration, cloud cover, and water vapor (Liu et al., 2017).

In this article we present results of two studies that evaluated the cognitive effects of UVR vis-à-vis European ancestry controlling for disease burden and income per capita, which are variables highly relevant to cognitive performance (Lynn \& Vanhanen, 2012).

\section{Study 1}

This study replicates the León (2016) study in the USA using UVR instead of absolute latitude and applying more rigorous statistical techniques.

\section{Method}

\section{Subjects}

The 48 contiguous USA states participated in the study.

\section{Measurements}

Cognitive performance. Math and reading scores from male and female public school students in 8th grade came from the 2013 report of National Assessment of Educational Progress, NAEP; to simplify the analysis, we obtained a NAEP average 
using standard scores. Informed consent and ethics committee processes were responsibility of the contractors in charge of data collection (National Center for Education Statistics, 2017).

European ancestry. León (2016) calculated the percentage of Whites in each state using data from the 2010 U.S. Census, based on self-identification.

UV radiation. We obtained a weighted sum of the monthly UV Index for each USA largest city per state with the exception of two states in which the capital city was targeted; the UV Index was reported in 2013 by the Climate Prediction Center of the National Weather Service.

Income and infection rate. Data on income per capita, originated in the 2015 report of the U.S. Department of Commerce, was submitted to a logarithmic transformation, a conventional practice in econometric research. Prevalence of infectious diseases encompassing cholera, measles, meningitis, pertussis, rubella, tetanus, and tuberculosis in 1993-2007 was obtained from Eppig et al. (2011).

\section{Analytic strategy}

Given the high correlations expected between variables, we decided to avoid the multicolinearity problem that would impair OLS regression and used seemingly unrelated regression (SUR) in a set of regression models (Zellner, 1962) using R (Henningsen \& Hamann, 2007). Bootstrapping was utilized to avoid consequences of violation of assumptions of the statistical models. Conventional standards of model fit to the data were utilized in the evaluation of path models: chi-squared divided by degrees of freedom $\left(\chi_{2} / \mathrm{df}\right)<2$ or 3 (Schreiber et al., 2006) and standardized root mean square residual (SRMR) $\leq .07$, comparative fit index (CFI) $\geq .93$, Tucker-Lewis index (TLI) $\geq .92$, and root mean square error of approximation(RMSEA) $\leq .07$ (Bagozzi \& Yi, 2012).

\section{Results}

UVR correlated $-.56(\mathrm{p}<.001)$ with European ancestry, $-.75(p<.001)$ with NAEP score, $-.50(p<.001)$ with $\log$ income, and .64 $(p<.001)$ with infection rate. European ancestry correlated .47 $(p=$ $.001)$ with NAEP score, $.05(p=.738)$ with log income, and -.906 $(p<.001)$ with infection rate. NAEP score correlated $.65(p<$ $.001)$ with $\log$ income and -.6o $(p<.001)$ with infection rate. And log income correlated $-.26(p=.071)$ with infection rate. Nonetheless, the results of SUR shown in Table 1 demonstrated that the European ancestry-NAEP score relationship was spurious. Whereas UVR predicted NAEP scores in the SUR analysis, European ancestry predicted log income negatively and infant mortality positively. 
Table 1. Results of seemingly unrelated regression models predicting three USA study variables from European ancestry, UV radiation, and the other study variables. $N=48$.

\begin{tabular}{|c|c|c|c|c|c|c|c|c|c|}
\hline \multirow[b]{2}{*}{ Predictors } & \multicolumn{3}{|c|}{ NAEP score } & \multicolumn{3}{|c|}{ Log income } & \multicolumn{3}{|c|}{ Infection rate } \\
\hline & $\beta$ & $95 \% \mathrm{CI}$ & $p$ & $\beta$ & $95 \% \mathrm{CI}$ & $p$ & $\beta$ & $95 \% \mathrm{CI}$ & $p$ \\
\hline European ancestry & -0.06 & $-0.49 ; 0.84$ & .786 & -0.74 & $-1.54 ;-0.30$ & .001 & -0.83 & $-1.07 ; 0.70$ & .001 \\
\hline UV radiation & -0.40 & $-0.54 ; 0.00$ & .006 & -0.18 & $-0.49 ; 0.27$ & .262 & 0.04 & $-0.25 ; 0.19$ & .653 \\
\hline Infection rate & -0.20 & $-0.87 ; 0.63$ & .407 & -0.46 & $-1.39 ; 0.12$ & .058 & & & \\
\hline Log income & 0.40 & $0.30 ; 0.95$ & .009 & & & & -0.09 & $-0.41 ; 0.27$ & .430 \\
\hline NAEP score & & & & 0.58 & $0.45 ; 1.20$ & .001 & -0.15 & $-0.47 ; 0.07$ & .104 \\
\hline Model fit (Adj. R²) & & $.69(p<.001)$ & & & $.55(p<.001)$ & & & $.86(p<.001)$ & \\
\hline
\end{tabular}

Figure 1 depicts the best-fitted path European ancestry increases the NAEP model we were able to formulate. In score through a powerful reduction of this model, UVR affects the NAEP score infection rate and shows a paradoxical directly and through log income whereas negative influence on log income.

Figure 1. Path coefficients, significance, and indicators of fit to the data for the USA path model that best fitted the data. $N=48$.

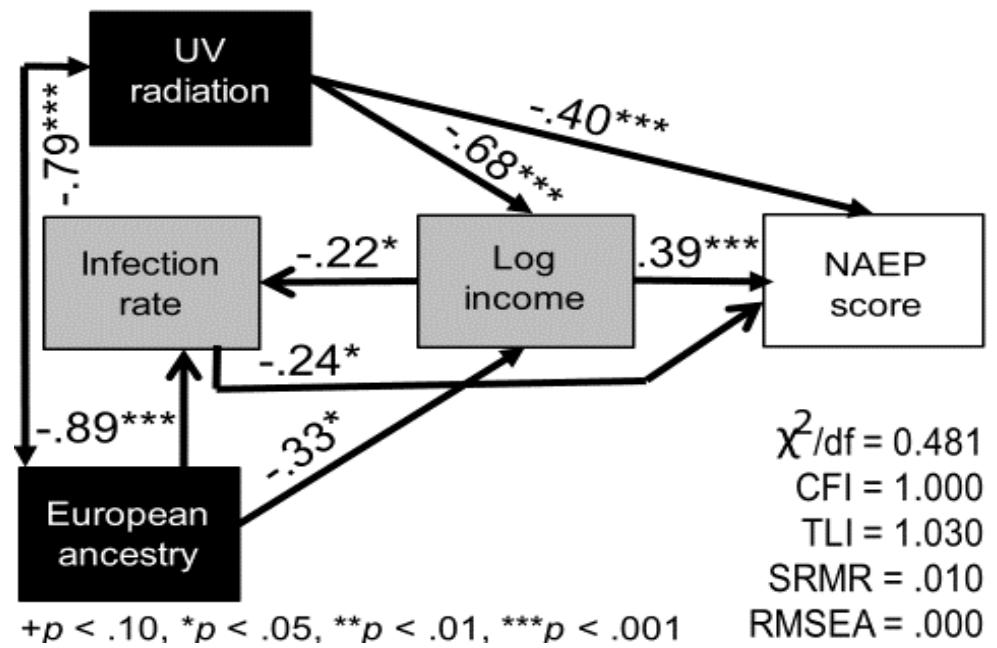




\section{Study 2}

\section{Method}

\section{Subjects}

The 27 states of Brazil were targeted, but the federal capital (Brasilia) was excluded because it lacked racial data; hence, the actual $\mathrm{N}$ was 26 .

\section{Measurements}

Cognitive performance. The study used math, reading, and science scores from successive PISA (Programme for International Student Assessment of the Organisation for Economic Co-operation and Development, OECD) rounds in Brazil for 2009, 2012, and 2015 targeting 15 yearolds. Lynn et al. (2017) have described the specific procedures used to obtain this aggregate PISA value from 62,082 Brazilian students. Informed consent and ethics issues can be seen in OECD (2016).

European ancestry. Fuerst and Kirkegaard (2016) averaged the state admixture values reported in Moura et al's meta-analysis referred to by Rodriguez de Moura et al. (2015) for 16 Brazilian states and complemented the data with estimates for the other 10 states using average values from the five major Brazilian regions; they reported a correlation $r=.74$ between European ancestry and cognitive ability.

$U V$ radiation. Measurements of this variable per state in 2013 were obtained for the present study from Schalka et al. (2014); the data were about a distribution of maximum UV radiation in the country on a day in August 2013.

Income and infant mortality. The next measurements came from Atlas Brazil (2013). The 2010 infant mortality rate was used as a proxy for infectious diseases.

\section{Analytic strategy}

We used the same techniques utilized in Study 1.

\section{Results}

UVR correlated $-.79(p<.001)$ with European ancestry, $-.82(p<.001)$ with PISA score, $-.83(p<.001)$ with $\log$ income, and .62 ( $p=.001)$ with infection rate. European ancestry correlated $.75(p<.001)$ with PISA score, .66 $(p<.001)$ with log income, and -.62 $(p=.001)$ with infection rate. PISA score correlated .83 $(\mathrm{p}<.001)$ with $\log$ income and $-.82(\mathrm{p}<$.oo1) with infection rate. And log income correlated $-.88(p<.001)$ with infection rate. As in the USA study, the results of SUR (Table 2) revealed the spuriousness of the European ancestry-cognitive ability relationship. Unlike the USA study, this study yielded direct linkages of UVR with cognitive ability, log income, and the proxy for infectious diseases (infant mortality), whereas European ancestry predicted only log income, and negatively. 
Table 2. Results of seemingly unrelated regression models predicting three Brazil study variables from European ancestry, UV radiation, and the other study variables. $N=26$.

\begin{tabular}{|lccccccccc|}
\hline & \multicolumn{3}{c}{ PISA score } & \multicolumn{3}{c}{ Log income } & \multicolumn{3}{c|}{ Infant mortality } \\
Predictors & $\boldsymbol{\beta}$ & $\mathbf{9 5} \% \mathbf{C I}$ & $\boldsymbol{p}$ & $\boldsymbol{\beta}$ & $\mathbf{9 5 \%} \mathbf{C I}$ & $\boldsymbol{p}$ & $\boldsymbol{\beta}$ & $\mathbf{9 5 \%} \mathbf{C I}$ & $\boldsymbol{p}$ \\
\hline European ancestry & -0.04 & $-0.47 ; 0.38$ & .826 & -0.17 & $-0.39 ; 0.10$ & .012 & -0.17 & $-0.40 ; 0.16$ & .173 \\
UV radiation & -0.85 & $-1.61 ;-0.09$ & .031 & -0.74 & $-1.10 ;-0.39$ & $<.001$ & -0.91 & $-1.35 ;-0.46$ & $<.001$ \\
Infant mortality & -0.92 & $-1.46 ;-0.16$ & .013 & -0.81 & $-1.03 ;-0.61$ & $<.001$ & & & \\
Log income & -0.68 & $-1.48 ; 0.44$ & .147 & & & & -1.08 & $-1.34 ;-0.78$ & $<.001$ \\
PISA score & & & & -0.34 & $-0.65 ; 0.21$ & .106 & -0.61 & $-0.87 ;-0.11$ & .012 \\
Model fit (Adj. $\left.\mathrm{R}^{2}\right)$ & & $.81(p<.001)$ & & & $.91(p<.001)$ & & & $.88(p<.001)$ & \\
\hline
\end{tabular}

Finally, Figure 2 depicts the best-fitted directly, whereas European ancestry path model. In this case, UVR influen- replicated the paradoxical relationship ced the three dependent variables with log income.

Figure 2. Path coefficients, significance, and indicators of fit to the data for the best-fitted path model in the Brazil study. $N=26$.

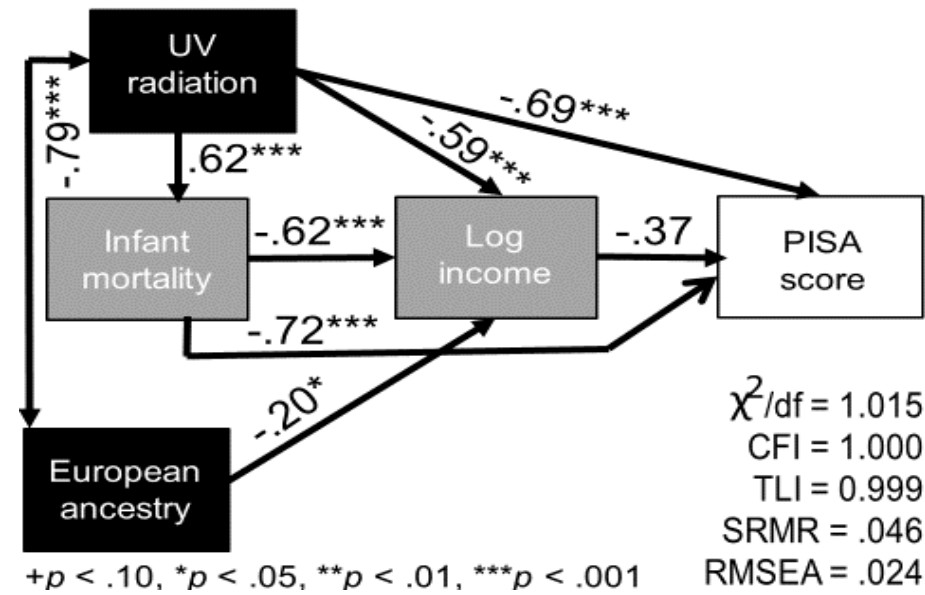

\section{Discussion and Conclusions}

The main limitation of the study was sample size, especially in Brazil $(\mathrm{N}=26)$. Another problem of the Brazilian study was the weak measurement of European ancestry, which was accomplished individually in each of 16 states, but had to beestimated for theother 10 states using averagevalues from thefive major Brazilian regions. Moreover, the one-day measurement of UV radiation in Brazil represented a clear weakness of the study. Therefore, it is difficult to ascertain whether the differences observed between the two 
studies are attributable to the doubling of the Brazilian sample sizeand use of stronger measurements in theUSA. Morecredibleasa causelooks thedifference between Braziland USA as countries (their geographic characteristics, history, and population). On the other hand, small samples and weak measurements do not bias results; they simply reduce the probability of finding significant relationships. In the present study strong and consistent findings emerged across two countries and two types of statistical analysis pointing to UV radiation as a credible direct source of decreased cognitive scores, whereas European ancestry only showed an indirect cognitive effect in the USA. These findings are particularly noteworthy considering the replicability crisis in psychology (Swiatkowski \& Dompnier, 2017; Koul et al., 2018). Cognitive effects of UV radiation based on alternative measures of cognitive ability have been reported for Italy (León \& Antonelli-Ponti, 2018a), United States (León \& Hassall, 2017; León \& Burga-León, 2018), Europe (León, 2018b), and 96 countries (León, 2018a), but this is the first time that such effects are demonstrated controlling for those of European ancestry.

The spurious race-IQ correlation extant in Brazil probablyowed to the fact that themain minority of Brazil (Africans, with $7 \%$, versus $48 \%$ Whites) and the $43 \%$ multiracial group reside predominantly close to the equator. African slaves were imported and sent to work in plantations located in regions of high UV radiation on the basis of the assumption that they were more resistant than Whites to parasites and heat stress. Similar was the case in the USA, where the African slaves were settled in the south.
The weakness shown by European ancestry as a source of cognitive and economic effects in our study is relevant to two audiences. Psychologists who do research on the relationship between European ancestry and cognitive variables should realize that their findings may be spurious. They are ethically challenged to test their favorite hypotheses using UVR as a likely confounder. Economists have explained national wealth as a spillover of European culture and institutions (Hall \& Jones, 1999; Acemoglu et al., 2001, 2014) and have used European ancestry as predictor in econometric analyses, either directly (Putterman \& Weil, 2010; Putterman, 2013; Chanda et al., 2014) or mediated by individualism (Gorodnichenko \& Rowland, 2017). Cultural economists should pay attention to our findings and to Andersen et al's (2016) demonstration of the strong negative effects of UVR on national wealth controlling for racial and cultural variables. Evidently, our findings do not challenge well-designed studies on the heritability of intelligence (e.g., Rushton\& Jensen, 2010; Sauce \& Matzel, 2018).

\section{Financing}

This research received no grant for any funding agency in the public, commercial, or not-for-profit sectors.

\section{Conflict of interest}

The authors declare no conflict of interest regarding moral, economic, labor and research issues. 


\section{References}

Acemoglu, D., Johnson, S., \& Robinson, J. A. (2001). The colonial origins of comparative development: An empirical investigation. American Economic Review, 91, 1369-1401. https://doi.org/10.1257/aer.91.5.1369

Acemoglu, D., Gallego, F. A., \& Robinson, J. A. (2014). Institutions, human capital, and development. Annual Review of Economics, 6, 875-912. https://doi.org/10.1146/ annurev-economics-080213-041119

Andersen, T. B., Dalgaard, C. J., \& Selaya, P. (2016). Climate and the emergence of global income differences. The Review of Economics Studies, 83, 1334-1363. https:// doi.org/10.1093/restud/rdwoo6

Atlas Brazil (2013). Atlas of Human Development in Brazil. http://www.atlasbrasil. org.br/2013/pt/consulta/

Bagozzi, R. P., \& Yi, Y. (2012). Specification, evaluation, and interpretation of structural equation models. Journal of the Academy of Marketing Science, 40, 8-34. https://doi.org/10.1007/s11747-011-0278-X

Becker, D., \& Rindermann, H. (2016). The relationship between cross-national genetics distances and IQ-differences. Personality and Individual Differences, 98, 300-310.

Chanda, A., Cook, C.J., \& Putterman, L. (2014). Persistence of fortune: Accounting for population movements, there was no post-colonial reversal. American Economic Journal, 6, 1-28. https://doi.org/10.1257/mac.6.3.1

Dvorkin, A. I., \& Streinberger, E. H. (1999). Modeling the altitude effect on solar UV radiation. Solar Energy, 65, 181-187. https://doi.org/10.1016/Soo38-092X(98)oo126-1

Engelsen, O., Brustad, M., Aksnes, L., \& Lund, E. (2005). Daily duration of vitamin D synthesis in human skin with relation to latitude, total ozone, altitude, ground cover, aerosols and cloud thickness. Photochemistry and Photobiology, 81, 12871290. https://doi.org/10.1562/2004-11-19-RN-375

Eppig, C., Fincher, C. L., \& Thornhill, R. (2011). Parasite prevalence and the distribution of intelligence among the states of the USA. Intelligence, 39, 155-16o. https:// doi.org/10.1016/j.intell.2011.02.008 
Fuerst, J., \& Kirkegaard, E. O. W. (2016a). Admixture in the Americas: Regional and national differences. Mankind Quarterly, 56, 3-73. https://doi.org/10.46469/ mq.2016.56.3.2

Fuerst, J. \& Kirkegaard, E. O. W. (2016b). The genealogy of differences in the Americas. Mankind Quarterly, 56, 425-481. https://doi.org/10.46469/mq.2016.56.3.9

Gorodnichenko, Y., \& Roland, G. (2017). Culture, institutions, and the wealth of nations. Review of Economics and Statistics, 99, 402-416. https://doi.org/10.1162/ REST_a_o0599

Hall, R. E., \& Jones, C. I. (1999). Why do some countries produce so much more output per worker than others? The Quarterly Journal of Economics, 114, 83-116. https://doi.org/10.1162/o03355399555954

Henningsen, A., \& Hamann, J. D. (2007). Systemfit: A package for estimating systems of simultaneous equations in R. Journal of Statistical Software, 23, 1-40. https:// doi.org /10.1.1.150.2837

Kirkegaard, E. O. W., \& Fuerst, J. (2017). Admixture in Argentina. Mankind Quarterly, 57, 542-580. https://doi.org /10.46469/mq.2017.57.4.4

Koul, A., Becchio, C., \& Cavallo, A. (2018). Cross-validation approaches for replicability in psychology. Frontiers in Psychology, 9, 1117. https://doi.org/10.3389/ fpsyg.2018.01117

León, F. R. (2016). Race vis-à-vis latitude: Their influence on intelligence, infectious diseases, and income. Mankind Quarterly, 56, 411-419. https://doi.org/10.46469/ mq.2016.56.3.7

León, F. R. (2018a). Diminished UV radiation enhances national cognitive ability, wealth, and institutions through health and education. Personality and Individual Differences, 120, 52-57. https://doi.org/10.1016/j.paid.2017.08.025

León, F. R. (2018b). Boundary conditions and new directions for UVR Theory: Reply to comments. Mankind Quarterly, 58, 673-685. https://doi.org/10.46469/ mq.2018.58.4.11

León, F. R., \& Antonelli-Ponti, M. (2018) UV radiation theory and the Lynn (2010) Italian debate. Mankind Quarterly, 58, 621-649. https://doi.org/10.46469/mq.2018.58.4.7 
León, F. R., \& Avilés, E. (2016) How altitude above sea level affects intelligence. Intelligence, 58, 33-41. https://doi.org/10.1016/j.intell.2016.06.001

León, F. R., \& Burga-León, A. (2014). Why complex cognitive ability increases with absolute latitude. Intelligence, 46, 291-299. https://doi.org/10.1016/j.intell.2014.07.011

León, F. R., \& Burga-León, A. (2015). How geography influences complex cognitive ability. Intelligence, 50, 221-227. https://doi.org/10.1016/j.intell.2015.04.011

León, F. R., \& Burga-León, A. (2018). UV radiation associates with state income through complex cognitive ability in the USA. Journal of Individual Differences, 39, 18-26. https://doi.org/10.1027/1614-0oo1/aooo245

León, F. R, \& Hassall, C. (2017). UV radiation is associated with latitudinal trends in cognitive ability of White children in the USA. Journal of Individual Differences, 38, 155-162. https://doi.org/10.1027/1614-0001/aooo232

Liu, H., Hu, B., Zhang, L., Zhao, X. J., Shang, K. Z., Wang, Y. Z., \& Wang, J. (2017). Ultraviolet radiation over China: Spatial distribution and trends. Renewable and Sustainable Energy Reviews, 26, 1371-1383. https://doi.org/10.1016/j.rser.2017.03.102

Lynn, R., Antonelli-Ponti, L., Mazzei, R., Da Silva, J., \& Meisenberg, G. (2017). Differences in intelligence and socio-economic outcomes across the twenty-seven states of Brazil. Mankind Quarterly, 57, 519-541. https://doi.org/10.46469/ $\mathrm{mq} \cdot 2017 \cdot 57 \cdot 4 \cdot 3$

National Center for Education Statistics. (2017). National assessment of educational progress (NAEP). http://nces.ed.gov/nationsreportcard/

OECD (2017). PISA-based tests for schools: Technical report 2016. https://www.oecd. org/pisa/aboutpisa/PfS_TechReport_CRC_final.pdf

Putterman, L. (2013). Institutions, social capability, and economic growth. Economic Systems, 37, 345-353. https://doi.org/10.1016/j.ecosys.2012.12.002

Putterman, L., \& Weil, D. N. (2010). Post-1500 population flows and the long-run determinants of economic growth and inequality. The Quarterly Journal of Economics, 125, 1627-1682. https://doi.org/10.1162/qjec.2010.125.4.1627 
Rindermann, H. (2007). The g-factor of international cognitive ability comparisons: The homogeneity of results in PISA, TIMSS, PIRLS and IQ-tests across nations. European Journal of Personality, 21, 667-706. https://doi.org/10.1002/per.634

Rodriguez de Moura, R., Coelho, A. V. C., de Queiroz Balbino, V., Crovella, S., \& Brandao, L. A. C. (2015). Meta-analysis of Brazilian genetic admixture and comparison with other Latin America countries. American Journal of Human Biology, 27, 674-68o. https://doi.org/10.1002/ajhb.22714

Rushton, J. P., \& Jensen, A. R. (2010). Race and IQ: A theory-based review of the research in Richard Nisbett's Intelligence and how to get it. The Open Psychology Journal, 3, 9-35. https://doi.org/10.2174/1874350101003010009

Sauce, B., \& Matzel, L. D. (2018). The paradox of intelligence: Heritability and malleability coexist in hidden gene-environment interplay. Psychological Bulletin, 144, 26-47. https://doi.org/10.1037/buloooo131

Swiatkowski, W., \& Dompnier, B. (2017). Replicability crisis in social psychology: Looking at the past to find new pathways for the future. International Review of Social Psychology, 30, 111-124. https://doi.org/10.5334/irsp.66

Schalka, S., Steiner, D., Ravelli, F. N., Steiner, T., Terena, A. C., Marçon, C. R., ... Duarte, I. (2014). Brazilian consensus on photoprotection. Anais Brasileiros de Dermatologia, 89, 1-74. http://dx.doi.org/10.159o/abd18o6-4841.20143971

Schreiber, J. B., Stage, F. K., King, J., Nora, A., \& Barlow, E. A. (2006). Reporting structural equation modeling and confirmatory factor analysis results: A review. The Journal of Educational Research, 99, 324-337. https://doi.org/10.3200/JOER.99.6.323-338

Zellner, A. (1962). An efficient method of estimating seemingly unrelated regressions and tests for aggregation bias. Journal of the American Statistical Association, 57, 348-368. https://doi.org/10.108o/01621459.1962.10480664

Recibido: 7 de junio de 2021

Revisado: 8 de agosto de 2021

Aceptado: 21 de setiembre de 2021 